\title{
DYNAMICS AND ASYMMETRIC RENT ADJUSTMENTS IN THE OFFICE MARKET IN WARSAW
}

\author{
Krzysztof NOWAK (1D) ${ }^{1}$, Michal GLUSZAK (D) ${ }^{2, *}$, Stanislaw BELNIAK (D) ${ }^{2}$ \\ ${ }^{1}$ Department of Financial Markets and Public Finance, University of Rzeszow, Rzeszow, Poland \\ ${ }^{2}$ Department of Real Estate and Investment Economics, Cracow University of Economics, Krakow, Poland
}

Received 19 November 2019; accepted 25 May 2020

\begin{abstract}
Dynamics of rent, vacancy, supply and demand on the office market of emerging commercial real estate markets have long been under-researched. The paper fills the gap in economic literature by investigating the growing office market in Warsaw. In particular, we evaluate whether the influence of demand and supply shocks differ depending on the current market conditions. Using Error Correction Model approach, we investigated the rent adjustments on the office market in Warsaw, which is the major property market in Central and Eastern Europe. We replaced variables of the basic model with asymmetric variables to check for asymmetric adjustments in the office market. The study period covers data from 2005:1Q to 2016:1Q. The empirical results suggest that demand shock had a stronger impact on rent when the market vacancy rate was below the average for the period considered. Additionally, the demand shock had a stronger impact on rent when the rent was above the equilibrium level.
\end{abstract}

Keywords: office market, rents, asymmetric adjustments, demand shock, supply shock, Poland.

\section{Introduction}

The vast majority of research on modelling the dynamics of the office market in the countries of Western Europe and the United States mainly concerns markets characterized by a large total stock. Real estate markets in developing countries often differ from their counterparts in developed countries, which is largely due to institutional conditions. This also applies to the countries of Central and Eastern Europe, which came undergoing systemic transformation, during which also a modern real estate market was formed. In that case, it is crucial to state a question whether patterns typical for developed countries, from which most of the office market research comes, can be found in the countries of Central and Eastern Europe. The article aims to contribute to the understanding of the real estate market dynamics, by investigating the office market in Poland. In a recent decade, the real estate sector in Poland has become an attractive market of interest to international investors. Despite huge institutional transformation since the 1990s growing and developing real estate market still cannot be compared to developed property markets in the US, UK, and Western Europe.

The history of the Polish real estate market began again with the beginning of political changes in Poland in 1989.
Directly after them, there were practically no buildings in Poland offering modern office space. Three stages can be distinguished in the development of the office market in Poland. At the beginning of the transformation period, the market of modern office space in Poland developed mainly in Warsaw as a result of the inflow of investors and foreign enterprises opening representative offices in the capital. In the years 1990-2000, the supply of this market increased by 1.44 million sq. m. (CBRE, 2014). In the next stage, i.e. in the years 2001-2010, the development of the office market was largely due to the inflow of investments from the business services sector (SSC/BPO). It contributed to the development of regional office markets mainly in Krakow, Wroclaw, Poznan, the Tricity (Gdansk, Gdynia, Sopot), but also to a lesser extent in Katowice or Lodz. Development of the office market both in Warsaw and in other cities, referred to as regional markets accelerated after Poland's accession to the European Union in 2004, which enabled a larger inflow of foreign investments. In Warsaw, the number of modern office buildings increased by 208 objects, representing a total stock of nearly 2 million sq. $\mathrm{m}$. The third stage in the years after 2010 is characterised by the slowly growing interest of smaller urban centres, among others Bydgoszcz, Szczecin, Lublin or Rzeszow (PAIiIZ \& JP Weber Dudarski Sp. k., 2015, p. 141; CBRE, 2015, p. 2; CBRE, 2017).

*Corresponding author. E-mail: gluszakm@uek.krakow.pl 
At the end of 2015 total stock of the modern office space in main nine cities in Poland was estimated at 7.5 million sq. m., out of which over $60 \%$ was situated in Warsaw (Colliers International, 2016, p. 7). The capital city is also the only city in Poland, where the new supply during the year has reached the size of several hundred thousand sq. $\mathrm{m}$. In other cities, its increase was usually from a few to several tens thousand sq. m. annually.

The article investigates the rent adjustments in one of the largest office markets in Central and Eastern Europe. Traditional models of functioning of office market assumed symmetric changes in rent and/or vacancy rate in response to demand and supply shocks. Currently, some papers on the subject emphasize that these reactions may be asymmetric, depending on the phase of the business cycle in this market (Hendershott et al., 2010; Brounen \& Jennen, 2009a; McCartney, 2012). The reaction may also depend on the type of shock (demand or supply), the direction of shock (positive or negative) and its magnitude.

The article addresses the problem of asymmetric adjustments in the office market in Warsaw. The main objective of the research is to assess whether in Polish conditions responses to demand and supply shocks differ depending on the type of shock and the phase of the business cycle in which the market is located. As a part of empirical research, the following research hypotheses were tested:

1. The response of rent to demand shocks is stronger if the current vacancy rate is lower than the average vacancy rate for the period under consideration.

2. The response of rent to demand shocks is stronger if in the previous period the rent was below the equilibrium level.

3. The response of rent to supply shocks is stronger if in the previous period the rent was above the equilibrium level.

The results obtained are compared to the previous studies on office markets in developed countries - mainly the United States and Western Europe. As indicated at the outset, most of the research conducted in these countries indicates that adjustments in office markets are asymmetric. However, this has not been confirmed for markets at an earlier stage of development, which include the office market in Poland.

The paper is organised as follows. Section 1 analyses the prior research on office market dynamics. Econometric methods and data gathering process are described in section 2 . Section 3 presents and discusses major findings, whereas Section 4 compares the results from Poland to previous empirical research. In the last section, some conclusions and implications are listed based on the major findings.

\section{Literature review}

Papers focusing on the modelling of the office market using the error correction model began to appear at the beginning of the XXI century. Initially, most of them focused on the construction of the model and presentation of the characteristics of the market being studied. However they did not consider possible scenarios of market developments, so they did not take into account the asymmetric dependencies of the model and the response to the impulse. This to the best of our knowledge changed after the article by Englund et al. (2008), who presented the market research in Stockholm. Based on a multi-equation model the authors assessed the market adjustment process to a positive demand shock.

In subsequent publications regarding office market, the previously not addressed issue of asymmetric adjustments began to appear. In most of the works dealing with this issue, the model was based on asymmetric variables which enable to depict the asymmetric nature of market adjustments. In this context, it is worth mentioning the publication of Brounen and Jennen (2009a), which was based on the study of panel data from 15 metropolitan areas in the United States. The study aimed to determine whether the rent response to positive changes on the demand side was stronger when the market vacancy rate was below the long-term average. The obtained results confirmed these assumptions. Hendershott et al. (2010) conducted a study of the office market in the City of London, broadly considering the asymmetric response to positive and negative demand and supply shocks. McCartney (2012) investigated the asymmetric adjustment in the office market in Dublin. The results obtained by McCartney (2012) showed that changes in the demand variable had a greater impact on rent adjustments when the market vacancy rate was at a relatively low level. Moreover, the study pointed out that the impact of negative demand changes on the rent was larger, contrary to what was expected. It was also shown that if in the previous period the rent was above the level of equilibrium, the increase in the demand variable more strongly affected the rent than in the reverse situation. Ibanez and Pennington-Cross (2013) focused on the impact of deviations of current rent from the equilibrium level on adjustments on four segments of the real estate market (office, retail, industrial and flex space) in 34 metropolitan areas in the United States, using panel data. The results were not statistically significant. However, they drew attention to issues that may affect the asymmetry of adjustments in the office market which have not been considered before. Farrelly et al. (2014), based on panel data from twelve major European office markets, verified the impact of positive and negative demand and supply shocks on adjustments in the office market. The results obtained by them were in line with expectations. They indicated, among other issues, that the model's reaction is greater when a positive demand or supply shock conducts the rent towards the level of equilibrium. Results of a Finnish study suggest that office rents adjustments were driven by both new office completions and macroeconomic factors (Kiehelä \& Falkenbach, 2014). Recently, office rent adjustments, both in the short and long run, have been investigated using Paris market data (Bruneau \& Cherfouh, 2015). 
Several studies addressed the well-developed office market in East Asia. Using office market data from Jakarta spanning from 1996 to 2012 Simon, Achsani, Manurung, and Sembel explored relations between rents and several macroeconomic variables. Using the VECM model they found that rental rates responded to services sector employment, exchange rate and economic growth (Simon et al., 2015). Interesting empirical evidence on the nature of rent determinants and rent adjustments comes from office markets in Hong Kong (Chau \& Wong, 2016) and Singapore (Ho et al., 2014).

To sum up, in the last decade several papers investigating office market dynamics in various geographic areas have been published. Nevertheless, the gap between the body of evidence coming from mature market economies (especially from office markets in major metropolitan areas) and emerging economies still exists. Despite the growing interest in emerging property markets, mainly due to data availability office market research has been traditionally dominated by US and UK studies. A good example is a long run investigation into rent dynamics in London covering 1867-1959 period (Devaney, 2010). Arguably similar endeavour would not be possible in most other major cities in the world. This was noticed by Kiehelä and Falkenbach (2014) and in many cases can be attributed to the aforementioned data availability issues (Raslanas \& Lukošiene, 2013). Few papers have addressed the dynamics of office market Central and Eastern Europe countries (including Poland), thus the article contributes to the ongoing economic debate on the nature of office rents adjustments.

\section{Methods and data}

\subsection{Econometric approach}

Error correction model was applied in the study to verify the relationship between demand and supply on the market of modern office space in Warsaw. This approach allows simultaneous consideration of long-term and shortterm relationships in the market by formulating two equations. The second being based on the changes in the studied processes. Estimation of parameters of both equations can be carried out based on the OLS method, i.e. the classical concept of linear regression.

In the article from 2002 Hendershott et al. (2002a) suggested the basis for modelling the office market based on the error correction model. In turn, Hendershott et al. (2002b) presented its application for modelling on panel data. The formula of the long-term equation originates from equating demand to rented part of the total market supply. Demand is expressed as follows (Hendershott et al., 2002b, p. 62):

$$
D=\lambda_{0} R \lambda_{1} E A \lambda_{2}
$$

where: $D$ - demand; $R$ - rent; $E A$ - variable expressing economic activity; $\lambda_{1}$ - price elasticity of demand (takes values below zero); $\lambda_{2}$ - income elasticity of demand (takes values greater than zero).

$$
D(R, E A)=(1-v)^{*} S U,
$$

where: $S U$ - the total market supply of office space; $v-$ the vacancy rate. Demand is equal to the rented, occupied supply of office space, not the total supply of office space, due to the presence of several factors. Firstly, because of transaction costs. Secondly, because in the given moment some of the tenants are bound by the existing lease agreements (Hendershott et al., 2010, p. 82). Brounen and Jennen (2009a, p. 339) additionally indicated the occurrence of search costs. The factors mentioned above mean that at the given moment demand does not equal supply. It is rather equal to the product of the occupancy rate $(1-v)$ and the total office space supply available on the market $(S U)$. After taking logs the equation describing the market rent takes the form:

$$
\ln R=-\gamma_{0}+\gamma_{1} \ln E A+\gamma_{2} \ln S U+\varepsilon_{t}
$$

where: $\gamma_{0}=\gamma_{2}\left[\ln \left(1-v^{*}\right)-\ln \lambda_{0}\right] ; \varepsilon_{t}=\gamma_{2}[\ln (1-v)-\ln$ $\left.\left(1-v^{*}\right)\right] ; v^{*}-$ is constant. Thus the influence of the vacancy rate on the market equilibrium was included by the authors (Hendershott et al., 2002b, p. 62) in the variable $\varepsilon_{t}$ expressing the error. The long-term equation (3) thus takes the form of the cointegrating relation. It should also be emphasised that the time series used to build the short-term equation, comprise first differences of the variables used in the long-term equation, and shall be stationary. Based on Hendershott et al. (2002b, p. 63), the short-term equation of the error correction model can be expressed as follows:

$$
r_{t}=\alpha_{0}+\alpha_{1} e \alpha_{t}+\alpha_{2} s u_{t}+\alpha_{3} u_{t-1}+\phi r_{t-1}
$$

where: $u_{t-1}$ - residuals from the long term equation, lagged one period; $r_{t-1}$ - rent, lagged one period. The stationarity of time series was verified by the ADF test. The Johansen test was used to assess cointegration. Both tests were referred to, among others in the paper of Hendershott et al. (2002a). The Breusch-Pagan test was used by McCartney (2012) to assess heterogeneity. McCartney (2012) also used the commonly used Durbin-Watson test to evaluate autocorrelation. In this paper, however, Breusch-Godfrey test was used, which, unlike the Durbin-Watson test, can be used for assessing autocorrelation not only of the first but also higher orders. Also, the Durbin-Watson test should not be used for models with an autoregressive component (McCartney, 2012, p. 223). Equations (3) and (4) are the basic long-term (cointegrating relation) and the short-term equations of error correction model used in this study to model the office market in Warsaw.

Verification of hypotheses regarding asymmetric adjustments in the office market took place by replacing the regular variables from the basic, symmetric model with asymmetric variables. The construction of these variables allows us to examine the nature of asymmetric adjustments in the office market. In the paper, the terms "demand shock" and "supply shock" are understood as the increase or decrease in the value of the demand and supply variable, respectively. The verification of the response 
to shocks requires the comparison of the differences between the coefficients of asymmetric variables and the coefficients of symmetric variables from the baseline model. This approach is widespread in the literature (see, e.g. Brounen \& Jennen, 2009a; McCartney, 2012; Ibanez \& Pennington-Cross, 2013; Farrelly et al., 2014).

\subsection{Office market data}

The article relies on quarterly data of rent for office space (dependent variable) and variables that depict fluctuations of demand and supply (explanatory, independent variables), from the first quarter of 2005 to the first quarter of 2016. Table 1 presents the characteristics of the time series used in the study.

Table 2 presents descriptive statistics of the time series employed in the study, while the dynamics of the data is presented in Figure 1.

The dependent variable is the rent expressed as the amount of euro paid monthly per one sq. $\mathrm{m}$. of office space. Time series of rent were obtained from the Polish branch of Cushman \& Wakefield. These are rent data referred to as "prime rents" quarterly, covering the Central Business Area. Time series consist of nominal rent, i.e. do not include taxes, periods free of rent and other incentives for tenants. The time series was made real with the use of HICP inflation for the euro area (Eurostat, 2018). Data concerning inflation in a monthly view (Eurostat, 2018) was used to indicate inflation on a quarterly basis. Obtained quarterly reports on inflation in the euro zone were implemented to obtain real rent. Rent adjustments were regulated based on the prices in the first quarter of 2005.

Literature analysis shows that the availability of data regarding the supply of office space located on the market is

Table 1. Characteristics of time series employed (source: own study)

\begin{tabular}{|l|l|}
\hline \multicolumn{1}{|c|}{ Time series } & \multicolumn{1}{c|}{ Quarterly } \\
\hline The time range of data & $\begin{array}{l}\text { 1st quarter of 2005 - 1st } \\
\text { quarter of 2016 }\end{array}$ \\
\hline Geographical area (city) & Warsaw \\
\hline $\begin{array}{l}\text { Time series of the dependent } \\
\text { variable (name in the model) }\end{array}$ & $\begin{array}{l}\text { Rent in EUR/sq. m./month } \\
\text { (LNRent) }\end{array}$ \\
\hline $\begin{array}{l}\text { Time series of demand } \\
\text { variable (name in the model) }\end{array}$ & $\begin{array}{l}\text { The number of workers in } \\
\text { the enterprise sector in thous. } \\
\text { (LNEmployment) }\end{array}$ \\
\hline $\begin{array}{l}\text { Time series of supply variable } \\
\text { (name in the model) }\end{array}$ & $\begin{array}{l}\text { The total stock of modern } \\
\text { office space in sq. m. } \\
\text { (LNSupply) }\end{array}$ \\
\hline
\end{tabular}

a vast issue. This results in various types of time series that have been used in such studies. Most authors obtained time series for determining the supply variable from consulting companies or other private institutions collecting statistic data. Some authors have made use of interpolation and supply modelling, to fill in the periods for which data was not available. An example can be work of Hendershott et al. (2002b). In turn, Hendershott et al. (2010) used a time series containing estimates of the total supply of space, supply in started buildings and completed buildings.

In our models, we used a time series of the total supply of office space available at a given time on the market. The time series were obtained from the consulting company Cushman \& Wakefield. Time series of the same characteristic has been used by McCartney (2012) and Farrelly et al. (2014).

To reflect the demand side on the office market, most authors used employment in the financial and business services sectors. Such time series have been used, by among others Hendershott et al. (2002b). Many authors refer to the time series of employment in the so-called FIRE sectors, i.e. finance, insurance and real estate and the business services sectors (Brounen \& Jennen, 2009a). These series differed from each other, which is obvious due to differences in statistical methodologies used. However, it can be concluded that the majority of time series expressing demand refers to employment in sectors from which tenants of office largely buildings originate. Nevertheless, it should be noted that in literature one can find papers that use other measures of demand for office space. Mouzakis and Richards (2007) used the gross value added of the business services sector. Moreover, one can find examples of the use of the gross domestic product at the local level (Brounen \& Jennen, 2009b) and gross national product at the national level (McCartney, 2012). Ke and White (2013) compared three models in which three different time series were used as demand variables - respectively employment, local gross domestic product and foreign direct investment.

In our opinion use of the gross domestic product and similar measures at a country level does not seem to be justified in Polish conditions. The economy in Poland is less geographically concentrated than in some other countries (e.g. Ireland). The share of the metropolitan area of Warsaw in the GDP of Poland is much smaller than Dublin's contribution to the Irish economy. Therefore time series of gross national product at the level of the whole country that was used by McCartney (2012) for studying the office market in Dublin, cannot be treated as a good alternative in Polish conditions. Besides, data collected in this respect by the Central Statistical Office (GUS) are

Table 2. Descriptive statistics of time series employed (source: own study)

\begin{tabular}{|l|c|c|c|c|c|}
\hline \multicolumn{1}{|c|}{ Time series } & Min. & Max. & Avg. & Med. & SD \\
\hline Rent (EUR/sq. m.) & 17,0 & 31,0 & 24,5 & 25,0 & 3,5 \\
\hline Stock (sq. m.) & 2251524 & 4751357 & 3407034 & 3428348 & 738543 \\
\hline Employment (thous. of people) & 880,8 & 1033,1 & 969,8 & 974,1 & 37,4 \\
\hline
\end{tabular}




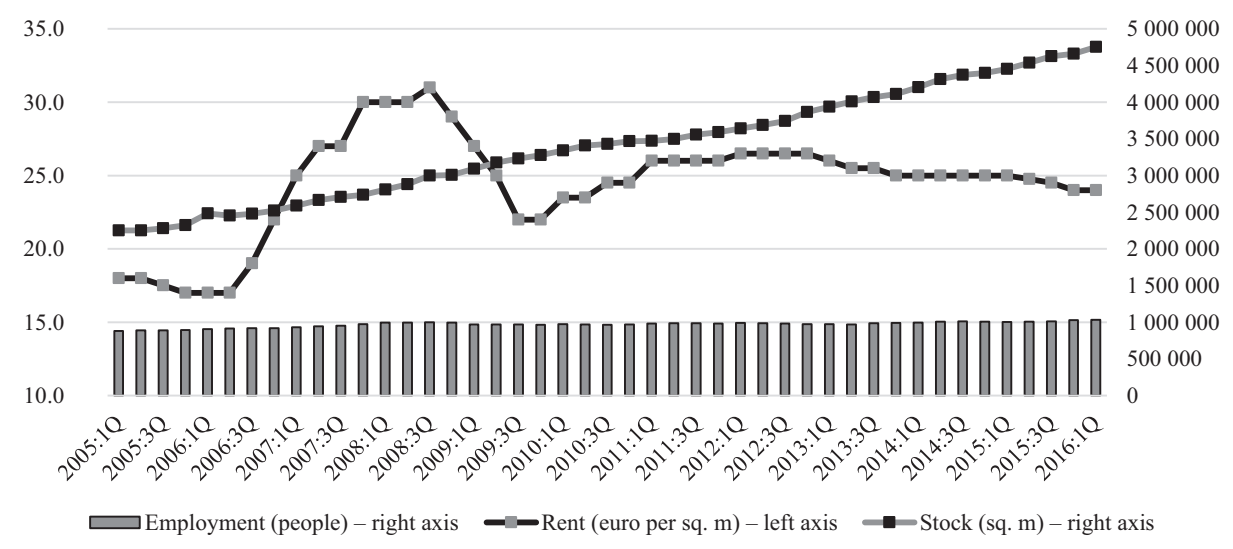

Figure 1. Dynamics of rent, stock and employment in Warsaw, 2005:1Q-2016:1Q (source: own study)

available only on an annual basis and time series are too short to be useful.

Application of employment time series in sectors that can be described as typical office tenants (that correspond to the previously mentioned FIRE sectors) was not possible due to PKD (Polish Classification of Activities, according to which data is collected by the Central Statistical Office) changes, which were carried out in 2004 and 2007. The changes in a structure of the data were such significant that unfortunately, it was not possible to build a consistent time series of appropriate length, regarding average employment or the number of people working in selected sections of the economy, which would approximate the FIRE sectors.

Due to the above, the time series used to build the model in this article are more aggregated data, which in our opinion illustrate changes in the economic situation and appropriately reflect changes in the demand for modern office space at the local level. Analogous data were used by Ke and White (2013) and Bruneau and Cherfouh (2015).

\section{Results}

\subsection{The symmetric model}

As a first step of the analysis, the symmetric ECM model was estimated. The study was performed in the Stata 13. The results of the long-term equation in the symmetric Model are presented in Table 3.
The parameters of both the demand and supply variables are statistically significant for $p$ equal to 0.01 . Coefficients are as expected positive and negative respectively however, differ significantly in terms of the value. Estimation of the demand variable coefficient takes value of 5.42 , while the supply variable coefficient stays at -0.75 . Adjusted $\mathrm{R}^{2}$ indicates a quite high model fit.

The short-term equation is based on the time series of changes of variables used in the long-term equation. The R_L1 variable, which represents lagged one-period residuals from the long-term equation, is included as another explanatory variable. It reflects the oscillations of difference of observed and estimated values of rent. Moreover in short-term equation variable LNRentClag is included to eliminate autocorrelation from the model. Such a procedure has already been used in literature. As pointed out by Englund et al. (2008, p. 102), the lagged dependent variable represents the element of cyclicality in the process of adjustments in the examined market. The short-term equation is presented in Table 4. In the case of the coefficient of the supply variable and constant, there is evidence of a lack of statistical significance.

Moreover, the coefficient of the supply variable is characterised by an inappropriate, i.e. positive sign and a value of 0.05 . The issue of the supply variable, i.e. positive value and/or lack of statistical significance was indicated by the majority of authors. Here we can recall for example following papers: Hendershott et al. (2002b), Hendershott

Table 3. The long-term equation in the symmetric model (source: own study)

\begin{tabular}{|l|c|c|c|}
\hline \multicolumn{1}{|c|}{ Dependent variable } & \multicolumn{2}{c|}{ LNRent } \\
\hline \multicolumn{1}{|c|}{ Independent variables } & Coefficient & Standard error & T statistic \\
\hline Constant & -22.9274 & 2.8759 & $-7.97^{*}$ \\
\hline LNEmployment & 5.4239 & 0.6028 & $9.00^{*}$ \\
\hline LNSupply & -0.7519 & 0.1067 & $-7.05^{*}$ \\
\hline Adjusted $R^{2}$ & \multicolumn{3}{|c|}{0.6482} \\
\hline Number of observations & \multicolumn{3}{|c|}{45} \\
\hline
\end{tabular}

Note: ${ }^{*} \mathrm{p}<0.01 ;{ }^{* *} \mathrm{p}<0.05 ;{ }^{* *} \mathrm{p}<0.1$. 
Table 4 . The short-term equation in the symmetric model (source: own study)

\begin{tabular}{|l|c|c|c|}
\hline Dependent variable & \multicolumn{3}{|c|}{ LNRentC } \\
\hline Independent variables & Coefficient & Standard error & T statistic \\
\hline Constant & -0.0038 & 0.0107 & $-0,35$ \\
\hline LNEmploymentC & 1.3838 & 0.7378 & $1.88^{\star * \star}$ \\
\hline LNSupplyC & 0.0549 & 0.5055 & 0.11 \\
\hline R_L1 & -0.2284 & 0.0822 & $-2.78^{\star}$ \\
\hline LNRentClag & 0.5534 & 0.1318 & $4.2^{\star}$ \\
\hline Adjusted R & & 0.3940 & 43 \\
\hline Number of observations & \multicolumn{3}{c}{} \\
\hline
\end{tabular}

Note: ${ }^{\star} \mathrm{p}<0.01 ;{ }^{* *} \mathrm{p}<0.05 ;{ }^{* *} \mathrm{p}<0.1$.

et al. (2002a), Mouzakis and Richards (2007), or Englund et al. (2008). Estimation of the demand coefficient does not come with similar problems, reaching the value of 1.38. Value of coefficient of lagged residuals from the long-term equation stays at -0.23 . In turn the coefficient of lagged rent is positive and equals 0.55 . The adjusted $\mathrm{R}^{2}$ for the short-term equation is lower than in long-term equation (0.39).

The presented model has been verified using econometric tests. First of all, the stationarity of the time series of used variables was evaluated. The results of the ADF test are presented in Table A1 in Appendix. The first three variables were used to build a long-term equation. The next three, whose time series are stationary formed the basis of the short-term equation. The results of the Johansen test, which was used to verify the cointegration between variables used in the long-term equation, are presented in Table A2. The null hypothesis for the rank zero was rejected, which means that there is at least one cointegrating vector. This confirms the existence of cointegration between variables. Table A3 presents the results of the Breusch-Godfrey test, which was implemented to verify the occurrence of autocorrelation in the short-term equation. The results of this test (1) indicate the occurrence of autocorrelation in the first form of the equation. Therefore, the second form of the equation was verified, which includes additional explanatory variable - already mentioned one period lagged change in rent (LNRentClag). Such a formula has been used, among others by Englund et al. (2008). The results of the Breusch-Godfrey test (2) located in the upper right of the Table A3 indicate the lack of autocorrelation in that case. Thus, the equation with an additional explanatory variable was considered the final form of the short-term equation. Table A3 presents also the result of the Breusch-Pagan test to confirm constant error variance. Obtained probability value, significantly exceeding the level of $\mathrm{p}$ equal to 0.1 indicates the lack of heteroscedasticity.

\subsection{The asymmetric models}

Asymmetric variables were introduced to the short-term equation of the model to verify the assumptions regarding asymmetric adjustments in the office market in Warsaw, in response to demand and supply shocks. Table 5 presents asymmetric variables and verified by them asymmetric dependencies on the office market in Warsaw. Short term equations with asymmetric variables are presented in Table 6.

Long-term average vacancy rate constitutes the average value of the market vacancy rate for the period considered in the study, i.e. from the first quarter of 2005 to the first quarter of 2016.

In the ECM approach, the equilibrium level on the market is represented by the long term equation. Simultaneously short-term equation depicts short term deviations from long-term equilibrium. According to that, rent fluctuations away from the level of equilibrium in the previous period were determined based on the value (positive or negative) of lagged one-period residuals from the longterm equation.

In the Model A1, the estimate of the coefficient of variable expressing changes in demand when the market vacancy rate was below the average of the examined period, was statistically significant. In this case, the parameter was about $60 \%$ higher than in the symmetric equation. Value of the coefficient of the asymmetric variable was 2.22 while the value for the symmetric variable from the basic equation was equal to 1.38 . This means that on the Warsaw market of modern office space, demand has a stronger impact on rent when the market vacancy rate is at a relatively low level. Such a result is in line with expectations as growing demand should translate into an increase in rent and a decrease in the market vacancy rate. As pointed out by McCartney (2012, p. 212), the market vacancy rate can only achieve positive values. The market vacancy rate can only decrease to a certain market-specific level above zero. The main reason is that office property managers tend to maintain a certain amount of free, vacant space. When this level is reached on a given market, a further increase in demand should result only in increasing rent, at an even faster pace than if the market rate of vacancy would be higher. In the short term equation of Model A1, statistical significance was also noted for the coefficient of residual parameters from the long-term equation and lagged dependent variable. 
Table 5. Asymmetric variables used in the asymmetric models (source: own study)

\begin{tabular}{|l|l|l|}
\hline \multirow{4}{*}{ Model } & \multicolumn{1}{|c|}{$\begin{array}{c}\text { Asymmetric variable } \\
\text { included in the model }\end{array}$} & \multicolumn{1}{c|}{ Type of the asymmetric relationship } \\
\hline \multirow{4}{*}{ Model A1 } & LNEmploymentC_A1H & $\begin{array}{l}\text { The change in demand has a stronger impact on rent if the market vacancy rate is } \\
\text { above the long-term average }\end{array}$ \\
\cline { 2 - 4 } Model A2 & LNEmploymentC_A1L & $\begin{array}{l}\text { The change in demand has a stronger impact on rent if the market vacancy rate is } \\
\text { below the long-term average }\end{array}$ \\
\cline { 2 - 4 } & LNEmploymentC_A2L & $\begin{array}{l}\text { The change in demand has a stronger impact on rent if in the previous period the } \\
\text { rent was above the equilibrium level } \\
\text { the rent was below the level of equilibrium }\end{array}$ \\
\hline \multirow{5}{*}{ Model A3 } & LNEmploymentC_A3H & $\begin{array}{l}\text { The change in demand has a stronger impact on rent if in the previous period the } \\
\text { rent has been above the equilibrium level }\end{array}$ \\
\cline { 2 - 4 } & LNEmploymentC_A3L & $\begin{array}{l}\text { The change in demand has a stronger impact on rent if the rent has been below } \\
\text { the level of equilibrium in the previous period }\end{array}$ \\
\cline { 2 - 4 } & LNSupplyC_A3H & $\begin{array}{l}\text { The change in supply has a stronger impact on rent if the rent has been above the } \\
\text { equilibrium level in the previous period }\end{array}$ \\
\cline { 2 - 4 } & LNSupplyC_A3L & $\begin{array}{l}\text { The change in supply has a stronger impact on rent if the rent has been below the } \\
\text { equilibrium level in the previous period }\end{array}$ \\
\hline
\end{tabular}

Note: Variable LNEmploymentC_A1H has been defined based on the time series obtained by multiplication of values of LNEmploymentC time series and a dummy variable, which takes value 1 if the market vacancy rate in the particular period is above the long-term average, and 0 otherwise. Consecutive asymmetric variables were produced in the same manner.

Table 6. The short-term equations with asymmetric variables (source: own study)

\begin{tabular}{|l|c|c|c|c|c|c|c|c|c|}
\hline \multirow{2}{*}{ Independent variables } & \multicolumn{3}{|c|}{ Model A1 } & \multicolumn{3}{c|}{ Model A2 } & \multicolumn{3}{c|}{ Model A3 } \\
\cline { 2 - 10 } & Coefficient & SE & $\mathrm{t}$ & Coefficient & SE & $\mathrm{t}$ & Coefficient & SE & $\mathrm{t}$ \\
\hline Constant & -0.0062 & 0.0106 & -0.59 & -0.0076 & 0.0107 & -0.71 & -0.0091 & 0.0120 & -0.75 \\
\hline LNEmploymentC_A1H & -0.3123 & 1.2709 & -0.25 & - & - & - & - & - & - \\
\hline LNEmploymentC_A1L & 2.2225 & 0.8884 & $2.50^{\star *}$ & - & - & - & - & - & - \\
\hline LNEmploymentC_A2H & - & - & - & 2.6951 & 1.0479 & $2.57^{\star}$ & - & - & - \\
\hline LNEmploymentC_A2L & - & - & - & 0.2157 & 0.9891 & 0.22 & - & - & - \\
\hline LNEmploymentC_A3H & - & - & - & - & - & - & 2.7036 & 1.0617 & $2.55^{*}$ \\
\hline LNEmploymentC_A3L & - & - & - & - & - & - & 0.2201 & 1.0018 & 0.22 \\
\hline LNSupplyC & 0.2589 & 0.5107 & 0.51 & 0.1690 & 0.4974 & 0.34 & - & - & - \\
\hline LNSupplyC_A3H & - & - & - & - & - & - & 0.3869 & 0.9265 & 0.42 \\
\hline LNSupplyC_A3L & - & - & - & - & - & - & 0.1374 & 0.5161 & 0.27 \\
\hline R_L1 & -0.2544 & 0.0821 & $-3.10^{*}$ & -0.2973 & 0.0896 & $-3.32^{*}$ & -0.3204 & 0.1225 & $-2.62^{*}$ \\
\hline LNRentClag & 0.4791 & 0.1369 & $3.50^{*}$ & 0.5255 & 0.1295 & $4.06^{*}$ & 0.5210 & 0.1321 & $3.94^{*}$ \\
\hline Prob > F & & 0.0001 & & & 0.0001 & & & 0.0002 \\
\hline Adjusted R & & 0.4189 & & & 0.4237 & & & 0.4090 \\
\hline
\end{tabular}

Note: ${ }^{*} \mathrm{p}<0.01 ;{ }^{* *} \mathrm{p}<0.05 ;{ }^{* *} \mathrm{p}<0.1$.

The coefficient of the statistically significant asymmetric demand variable in the equation of Model A2 was 2.70, nearly $100 \%$ higher than for demand variable in the symmetrical equation. Such a result suggests that demand more strongly influence rent when in the previous period the rent was above the equilibrium level. It could be expected that the demand will have a stronger impact on rent when in the earlier period it is below the equilibrium level. The equation of Model A2 indicates that even though the rent was in the previous period at a relatively high level, demand affects rent stronger than in the symmetric equation. In that case, demand is pulling rent away from the equilibrium level. Confirmation of this process can be found in the short term equation of Model A3. In which only an asymmetric variable formulated in the same way as in Model A2 was statistically significant. Its coefficient has reached a similar value (2.70), about twice as high as that of the symmetric equation. In equations of both Model 2 and Model 3 coefficients of residuals from the long-term equation and lagged dependent variable were statistically significant. 
We tested for statistical differences between symmetric and asymmetric coefficients. The results indicate that there is a statistically significant difference of coefficients between variables LNEmploymentC_A2H and LNEmploymentC_A2L, as well as LNEmploymentC_A3H and LNEmploymentC_A3L, at p-value 0,1 . This has not been confirmed for asymmetric variables in Model A1 and supply variables in Model A3.

Estimations of coefficients of statistically significant asymmetric variables are compared to the coefficient of the corresponding symmetric variable in Table 7 .

Table 7. Comparison of coefficients between the asymmetric variables and related symmetric variables (source: own study)

\begin{tabular}{|c|c|c|c|c|}
\hline Model & $\begin{array}{c}\text { Symmetric/ } \\
\text { asymmetric } \\
\text { variable }\end{array}$ & $\begin{array}{c}\text { Coef- } \\
\text { ficient }\end{array}$ & T statistic & $\begin{array}{c}\text { Adjusted } \\
\mathrm{R}^{2} \text { of the } \\
\text { model }\end{array}$ \\
\hline $\begin{array}{c}\text { Symmetric } \\
\text { model }\end{array}$ & $\begin{array}{c}\text { LNEmploy- } \\
\text { mentC }\end{array}$ & 1.3838 & $1.88^{\star * *}$ & 0.3940 \\
\hline Model A1 & $\begin{array}{c}\text { LNEmploy- } \\
\text { mentC_A1L }\end{array}$ & 2.2225 & $2.50^{* *}$ & 0.4189 \\
\hline Model A2 & $\begin{array}{c}\text { LNEmploy- } \\
\text { mentC_A2H }\end{array}$ & 2.6951 & $2.57^{\star}$ & 0.4237 \\
\hline Model A3 & $\begin{array}{c}\text { LNEmploy- } \\
\text { mentC_A3H }\end{array}$ & 2.7036 & $2.55^{\star}$ & 0.4090 \\
\hline
\end{tabular}

Note: ${ }^{*} \mathrm{p}<0.01 ;{ }^{* *} \mathrm{p}<0.05 ;{ }^{* *} \mathrm{p}<0.1$.
Is worth mentioning that not only asymmetric coefficients are higher in absolute values but also the model fit in case of Models 1, 2 and 3 is better than in the basic, symmetric model.

\section{Discussion}

\subsection{The symmetric model}

Tables 8 and 9 present a comparison of the long-term and short-term equations obtained for the symmetric model for the office market in Warsaw with the results of similar research, mainly from developed countries. Brounen and Jennen (2009b) in their work built models on data at the national and local level. Although the results presented by these authors are similar in both cases, however, we refer only to the results obtained for models based on local data, as the model developed by us is also based on local data. A similar approach has been applied to the specificity of the time series used by various authors. As far as the demand variable is concerned, most of the presented results concern the series referring to employment in sectors, which to a large extent determine the demand for modern office space. The exceptions are the results obtained by McCartney (2012), who used Gross National Product for Ireland. In turn, Ke and White (2013) in the presented model, used a time series regarding employment.

Table 8. Comparison of coefficients of long-term equation of the symmetric model with previous studies (source: own study)

\begin{tabular}{|c|c|c|c|c|c|}
\hline $\begin{array}{c}\text { Publication } \\
\text { (Authors) }\end{array}$ & Constant & $\begin{array}{l}\text { Demand } \\
\text { variable }\end{array}$ & $\begin{array}{c}\text { Supply } \\
\text { variable }\end{array}$ & Model fit ${ }^{*}$ & Explanation \\
\hline Model for Warsaw & -22.927 & 5.424 & -0.752 & 0.648 & ${ }^{*}$ for all models, the values represent Adjusted $\mathrm{R}^{2}$ \\
\hline $\begin{array}{l}\text { Hendershott et al. } \\
(2002 b)\end{array}$ & 6.63 & 1.25 & -2.78 & 0.282 & Model for the office market in London \\
\hline $\begin{array}{l}\text { Hendershott et al. } \\
(2002 a)\end{array}$ & 10.43 & 2.89 & -1.87 & 0.700 & $\begin{array}{l}\text { Model for the office market in the City of London, Supply } \\
\text { variable defined as the total supply of office space }\end{array}$ \\
\hline $\begin{array}{l}\text { Hendershott et al. } \\
(2002 \mathrm{a})\end{array}$ & 15.90 & 3.80 & -4.14 & 0.800 & $\begin{array}{l}\text { Model for the office market in the City of London, } \\
\text { Supply variable defined as the supply of rented office } \\
\text { space }\end{array}$ \\
\hline Stevenson (2007) & $\begin{array}{l}\text { from } \\
-92.43 \text { to } \\
-25.37\end{array}$ & $\begin{array}{c}\text { from } 3.963 \\
\text { to } 6.381\end{array}$ & $\begin{array}{l}\text { from } \\
-10.723 \text { to } \\
-0.490\end{array}$ & $\begin{array}{l}\text { from } 0.286 \\
\quad \text { to } 0.846\end{array}$ & $\begin{array}{l}\text { Models for the office market in } 4 \text { parts of London } \\
\text { (City, West End, Midtown, Docklands), in the model as } \\
\text { an additional independent variable there is a vacancy } \\
\text { rate for which the coefficients range from }-13.477 \text { to } \\
-0.955\end{array}$ \\
\hline $\begin{array}{l}\text { Englund et al. } \\
(2008)\end{array}$ & 13.499 & 1.880 & -1.803 & 0.786 & Model for the office market in Stockholm \\
\hline $\begin{array}{l}\text { Hendershott et al. } \\
(2010)\end{array}$ & 14.63 & 3.02 & -5.22 & 0.880 & $\begin{array}{l}\text { Model for the office market in the City of London, data } \\
\text { from 1977-1996 }\end{array}$ \\
\hline $\begin{array}{l}\text { Hendershott et al. } \\
(2010)\end{array}$ & 18.67 & 1.90 & -4.95 & 0.760 & $\begin{array}{l}\text { Model for the office market in the City of London, data } \\
\text { from 1977-2006 }\end{array}$ \\
\hline McCartney (2012) & 9.164 & 1.507 & -0.886 & 0.698 & $\begin{array}{l}\text { Model for the office market in Dublin, Demand } \\
\text { variable defined as the Gross National Product of } \\
\text { Ireland }\end{array}$ \\
\hline $\begin{array}{l}\text { Ke and White } \\
(2013)^{(9)}\end{array}$ & -0.147 & 1.237 & -0.239 & 0.752 & $\begin{array}{l}\text { Model for the office market in Beijing, in the model as } \\
\text { an additional independent variable there is a "coverage } \\
\text { rate" (1-v) for which the coefficient was } 0.188\end{array}$ \\
\hline $\begin{array}{l}\text { Ke and White } \\
(2013)^{(10)}\end{array}$ & -3.020 & 2.089 & -0.383 & 0.872 & $\begin{array}{l}\text { Model for the office market in Shanghai, in the model } \\
\text { as an additional independent variable, there is a } \\
\text { coverage rate (1-v) for which the coefficient was } 0.256\end{array}$ \\
\hline
\end{tabular}


Table 9. Comparison of coefficients of short-term equation of the symmetric model with previous studies (source: own study)

\begin{tabular}{|c|c|c|c|c|c|c|c|}
\hline $\begin{array}{l}\text { Publication } \\
\text { (Authors) }\end{array}$ & Constant & $\begin{array}{l}\text { Demand } \\
\text { variable }\end{array}$ & $\begin{array}{l}\text { Supply } \\
\text { variable }\end{array}$ & Residuals & $\begin{array}{l}\text { Additional } \\
\text { variable }\end{array}$ & $\begin{array}{l}\text { Model } \\
\text { fit }\end{array}$ & $\begin{array}{c}\text { Explanation } \\
\text { *for all models, the values represent } \\
\text { Adjusted } \mathrm{R}^{2}\end{array}$ \\
\hline $\begin{array}{l}\text { Model for } \\
\text { Warsaw }\end{array}$ & -0.004 & 1.384 & 0.055 & -0.228 & 0.553 & 0.394 & $\begin{array}{l}\text { An additional variable is the change in } \\
\text { rent lagged by one period }\end{array}$ \\
\hline $\begin{array}{l}\text { Hendershott } \\
\text { et al. }(2002 \mathrm{~b})\end{array}$ & -0.12 & 4.20 & 0.77 & -0.04 & - & 0.398 & Model for the office market in London \\
\hline $\begin{array}{l}\text { Hendershott } \\
\text { et al. }(2002 \mathrm{~b})\end{array}$ & -0.08 & 2.69 & 0.91 & -0.19 & 0.50 & 0.585 & $\begin{array}{l}\text { Model for the office market in London, } \\
\text { an additional variable is a change in rent } \\
\text { lagged by one period }\end{array}$ \\
\hline $\begin{array}{l}\text { Hendershott } \\
\text { et al. }(2002 \mathrm{a})\end{array}$ & -0.024 & 1.13 & 1.99 & -0.95 & - & 0.810 & $\begin{array}{l}\text { Model for the office market in the City of } \\
\text { London, Supply variable defined as the total } \\
\text { supply of office space }\end{array}$ \\
\hline $\begin{array}{l}\text { Hendershott } \\
\text { et al. }(2002 a)\end{array}$ & -0.005 & 2.09 & -1.72 & -0.72 & - & 0.690 & $\begin{array}{l}\text { Model for the office market in the City of } \\
\text { London, Supply variable defined as the sup- } \\
\text { ply of rented office space }\end{array}$ \\
\hline $\begin{array}{l}\text { Stevenson } \\
(2007)\end{array}$ & $\begin{array}{l}\text { from } \\
-0.024 \text { to } \\
0.001\end{array}$ & $\begin{array}{l}\text { from } \\
0.804 \text { to } \\
2.791\end{array}$ & $\begin{array}{l}\text { from } \\
-4.532 \text { to } \\
-0.284\end{array}$ & $\begin{array}{l}\text { from } \\
-0.226 \text { to } \\
-0.094\end{array}$ & $\begin{array}{l}\text { from } \\
-4.831 \text { to } \\
0.478\end{array}$ & $\begin{array}{l}\text { from } \\
0.177 \text { to } \\
0.41\end{array}$ & $\begin{array}{l}\text { Models for the office market in } 4 \text { parts } \\
\text { of London (City, West End, Midtown, } \\
\text { Docklands), in the model as an additional } \\
\text { explanatory variable there are changes in } \\
\text { the vacancy rate }\end{array}$ \\
\hline $\begin{array}{l}\text { Englund et al. } \\
\text { (2008) }\end{array}$ & 0.188 & 1.216 & -1.378 & -0.378 & $\begin{array}{c}3 \text { ad- } \\
\text { ditional } \\
\text { variables }\end{array}$ & 0.581 & $\begin{array}{l}\text { Model for the office market in Stockholm, } \\
\text { additional independent variables are the } \\
\text { change in rent lagged by one and two } \\
\text { periods and a time series of vacancy rates } \\
\text { lagged by one period, their coefficients } \\
\text { values: }-0.322 ;-0.322 ;-1.974 \text { respectively, } \\
\text { results from the system of equations for- } \\
\text { mulated based on SUR approach }\end{array}$ \\
\hline $\begin{array}{l}\text { Hendershott } \\
\text { et al. (2010) }\end{array}$ & 0.01 & 2.82 & -1.30 & -0.86 & -0.71 & 0.830 & $\begin{array}{l}\text { Model for the office market in the City of } \\
\text { London, data for the period 1978-1996, } \\
\text { an additional variable defined as changes } \\
\text { in the vacancy rate lagged by one period }\end{array}$ \\
\hline $\begin{array}{l}\text { Hendershott } \\
\text { et al. (2010) }\end{array}$ & 0.04 & 2.24 & -2.39 & -0.44 & -0.92 & 0.690 & $\begin{array}{l}\text { Model for the office market in the City of } \\
\text { London, data for the period 1978-2006, } \\
\text { an additional variable defined as changes } \\
\text { in the vacancy rate lagged by one period }\end{array}$ \\
\hline $\begin{array}{l}\text { Hendershott } \\
\text { et al. (2010) }\end{array}$ & 0.06 & 2.00 & -3.04 & -0.44 & -0.95 & 0.680 & $\begin{array}{l}\text { Model for the office market in the City of } \\
\text { London, data for the period } 1980-2006, \\
\text { an additional variable defined as changes } \\
\text { in the vacancy rate lagged by one period, } \\
\text { results from the system of equations for- } \\
\text { mulated based on SUR approach }\end{array}$ \\
\hline $\begin{array}{l}\text { McCartney } \\
(2012)\end{array}$ & 0.002 & 0.965 & -0.205 & -0.194 & 0.548 & 0.889 & $\begin{array}{l}\text { Model for the office market in Dublin, } \\
\text { Demand variable defined as the Gross } \\
\text { National Product of Ireland, the additional } \\
\text { variable defined as the change in rent } \\
\text { lagged by one period, the second ad- } \\
\text { ditional variable is lagged by one-period } \\
\text { time series of vacancy rate with coefficient } \\
-0.003\end{array}$ \\
\hline $\begin{array}{l}\text { Ke and White } \\
(2013)\end{array}$ & -0.019 & 2.101 & -0.075 & -0.435 & 0.250 & 0.298 & $\begin{array}{l}\text { Model for the office market in Beijing, the } \\
\text { additional variable defined as the change in } \\
\text { rent lagged by one period, the second ad- } \\
\text { ditional variable is the change in the "occu- } \\
\text { pancy rate" (1-v) with coefficient } 0.127\end{array}$ \\
\hline $\begin{array}{l}\text { Ke and White } \\
(2013)\end{array}$ & -0.006 & 1.483 & -0.308 & -0.393 & 0.166 & 0.295 & $\begin{array}{l}\text { Model for the office market in Shanghai, the } \\
\text { additional variable defined as the change in } \\
\text { rent lagged by one period, the second ad- } \\
\text { ditional variable is the change in the "occu- } \\
\text { pancy rate" (1-v) with coefficient } 0.107\end{array}$ \\
\hline
\end{tabular}


It should also be noted that many authors pointed out econometric issues. For instance, Hendershott et al. (2002a) reported problems with autocorrelation and/or heterogeneity in models based on the ECM approach consisting of two equations. However, these problems did not occur when one equation ECM model was formulated. In the empirical part of this article, we state a two-equation model, which is why the results of such models of other authors were compared. Also, it should be stressed that the short-term equations of Englund et al. (2008) in Table 9 and the third equation of Hendershott et al. (2010) come from systems of several equations built by these authors. The systems also consisted of equations explaining, respectively, the change in the vacancy rate, the change in supply, the change in employment in the first case, and the change in the vacancy rate and the change in supply in the second publication. It should be noted that our models were developed on quarterly data. The rest of the equations in Tables 8 and 9 were developed on an annual basis, except for these presented by Ke and White (2013), who used the six-month time series.

Coefficient of the demand variable in the long-term equation of our model reaches the highest value, apart from the results of Stevenson (2007). In all models presented in Table 8 , the coefficients of the supply variable are negative. The supply coefficient in the model for Warsaw is closest to those given by McCartney (2012) and by Ke and White (2013) as they stay above -1.0 . The adjusted $\mathrm{R}^{2}$ for the Warsaw model generally does not differ significantly from those obtained in other studies. In general, when it comes to the long-term equation the results for the Warsaw office space market are most similar to Dublin, London interior markets and emerging markets in Beijing and Shanghai.

In the short-term equation, the coefficient for the demand variable in the Warsaw model is below the average of the range for all models, which is between 0.80 and 4.20. Its value in Warsaw model is 1.38 . It is similar to those of the City of London (the first equation of Hendershott et al., 2002a), Stockholm (Englund et al., 2008) and Shanghai (second equation from Ke \& White, 2013). The coefficient for the demand variable in the Warsaw model is statistically significant for $\mathrm{p}$ level equal to 0.1 , while for the supply variable lack of significance is noted. Moreover, the supply variable has a positive sign, other than expected. Similar results were observed in three models of other authors presented in Table 9. It is also worth noting that in the model for the Warsaw office market, the absolute value of the coefficient of the supply variable is the lowest.

Coefficients of the residual parameters from all equations presented in Table 9 are negative. The absolute value of the coefficient in the case of the Warsaw model is situated in the upper half of the values in Table 9. In most equations shown in Table 9, there are additional explanatory variables included. In Warsaw model lagged one-period dependent variable, i.e. change in rent, was used. The respective coefficient equals 0.55 and is close to values of the same variables in the second equation of Hendershott et al. (2002b) and McCartney (2012). That is to the markets in London and Dublin. The values in models built by Ke and White (2013) were significantly lower. To sum up, seven out of the fifteen (including 4 equations proposed by Stevenson, 2007) equations in Table 9 were characterised by close to or lower values than in the Warsaw model, when it comes to the adjusted $\mathrm{R}^{2}$. In the case of the shortterm equation, values of coefficients for the office market in Warsaw are not similar to the results of specific previous studies listed in Table 9.

\subsection{The asymmetric models}

Based on the asymmetric short-term equation, three short-term asymmetric equations have been formulated. Statistically significant asymmetric variables presented in Tables 6 and 7 indicate that: (1) the change in demand has a stronger impact on the change of rent if the market vacancy rate is below the long-term average, and (2) the change in demand has a stronger impact on the change of rent if in the previous period the rent was above the equilibrium level.

The dependence stated in 1 . was also tested by McCartney (2012) for the office market in Dublin. The results obtained by McCartney (2012) indicated that growth of demand had a stronger effect on rent when the market vacancy rate was below 3.5\%. McCartney (2012) also showed that in the office market in Dublin, demand had a stronger impact on rent if, in the previous period, rent was above the equilibrium level. This confirms the result obtained also for the Warsaw office market, indicated in 2. above. Evaluation of analogous dependencies on the office market in 34 metropolitan areas in the United States was subject of study based on panel data, by Ibanez and Pennington-Cross (2013). However, due to the lack of statistical significance, they could not confirm similar conclusions. Hendershott et al. (2010) also examined the impact of demand and supply shocks on rent depending on whether the rent in the previous period was above or below the equilibrium level. The results obtained by them indicated that shocks have a greater impact on rent when they drive it towards the equilibrium level. Although the coefficients of considered variables had expected signs and magnitude, they also showed no statistical significance. Farrelly et al. (2014) based on research on panel data for 12 cities in Western Europe reported that the rent response to the positive demand shock was stronger if the rent in the previous period was below the equilibrium level.

In our opinion such an unexpected result in Warsaw case stated in (2), is an evidence of the office market cyclicality. Within the upward phase of the cycle, rent can increase during a several/many periods in a row. The assumption that in every market conditions after each increase in rent in the next period we shall witness rent decrease seems to be unrealistic, especially regarding the quarterly data on which the study is based. Moreover, most papers regarding the dynamics of the office market indicate that - due to the time-consuming investment 
process - it takes two to three years for supply to respond to demand changes. In our opinion, two to three years shall be the interval at which one shall look for the significant increase in supply to occur in the market, as a response to previous demand increase - which should pull rent back. Last but not least, such a result in the Warsaw office market can be attributed to market specificity. The office space market in Warsaw is a secondary European market, at an earlier stage of development than markets in Western Europe or the USA. This may be reflected by fewer supply constraints and greater sensibility to cyclical fluctuations, as the inflow of new supply means greater increase considered as a part of the total stock.

\section{Conclusions}

The research contributes to the ongoing research on office market dynamics and rent adjustments. The value added is twofold. Firstly, even though in recent decade several papers have focused on the fluctuation of office rents on emerging property markets, a literature review suggests that existing empirical evidence is coming mostly from developed markets in the US and the UK. There is a reason to believe that some of the findings are not fully representative of emerging economies and growing office markets in Central and Eastern Europe. The paper contributes to the body of knowledge, as it compares evidence from Warsaw to prior research coming from major office markets in developed countries. Secondly, only recently asymmetric office market changes have been investigated empirically. Paper provides additional insights into the nature of asymmetric rent adjustments.

The results obtained in the study indicate that in the office market in Warsaw:

1. The demand shock has a stronger impact on rent if the market vacancy rate is below the average for the period considered (confirmed hypothesis 1).

2. The demand shock has a stronger impact on rent if in the previous period the rent was above the equilibrium level (contrary to what we expected, see hypothesis 2).

In turn, we have not observed that in Warsaw Office market the adjustment of rent to supply shocks was stronger when in the previous period the rent was above the equilibrium level (thus hypothesis 3 has not been confirmed).

In our opinion, further work on the dynamics of the office market in Poland and Central and Eastern Europe should focus first on the impact of shocks on adjustments on the office market over more than one period. Provided the reliable data is available, future research should be based on a system of equations, where apart from changes in rent, also the market vacancy rate, the demand and supply would be treated as dependent variables. Comparison of the results of such research to those for the markets in the United States and Western Europe would allow to fully assess the differences in the dynamics of the office market in developed countries and countries of Central and Eastern Europe.

\section{Funding}

MG and SB acknowledge financial support from the funds allocated to the development of research potential of the Faculty of Economics and International Relations of the Cracow University of Economics. KN acknowledge financial support from the funds allocated to the development of research potential of the Institute of Economics and Finance of the University of Rzeszow.

\section{Author contributions}

MG, KN and SB conceived the study and were responsible for the design and development of the data analysis. $\mathrm{KN}$ was responsible for data collection and analysis. KN and $\mathrm{MG}$ were responsible for the literature review. $\mathrm{KN}$, $\mathrm{MG}$ and $\mathrm{SB}$ were responsible for data interpretation. $\mathrm{KN}$, MG wrote the first draft of the article. SB supervised and revised the manuscript.

\section{Disclosure statement}

Authors declare they do not have any competing financial, professional, or personal interests from other parties.

\section{References}

Brounen, D., \& Jennen, M. (2009a). Asymmetric properties of office rent adjustment. Journal of Real Estate Finance and Economics, 39(3), 336-358. https://doi.org/10.1007/s11146-009-9188-9

Brounen, D., \& Jennen, M. (2009b). Local office rent dynamics. A tale of ten cities. Journal of Real Estate Finance and Economics, 39(4), 385-402. https://doi.org/10.1007/s11146-008-9118-2

Bruneau, C., \& Cherfouh, S. (2015). Long-run equilibrium for the Greater Paris office market and short-run adjustments. Journal of Property Research, 32(4), 301-323. https://doi.org/10.1080/09599916.2015.1089310

CBRE. (2014). 25 lat polskiego rynku nieruchomości biurowych. http://www.cbre.pl/portal/pls/portal/CBWEB.utils_news_public.show_image? id=16948\&field=doc1\&trans $=y$

CBRE. (2015). Poland office destinations. http://www.officego.pl/img/cms/publications/Poland_Office_Destinations_2015_19_08_2015_04_56_37.pdf

CBRE. (2017). Rynek biurowy w strefie City Centre West. https:// idealab.cbre.pl/wp-content/uploads/2017/10/rynekbiurowywstrefiecitycentrewest.pdf

Chau, K. W., \& Wong, S. K. (2016). Information asymmetry and the rent and vacancy rate dynamics in the office market. Journal of Real Estate Finance and Economics, 53(2), 162-183. https://doi.org/10.1007/s11146-015-9510-7

Colliers International. (2016). Market insights. Polska, raport roczny 2016. http://www.colliers.com/pl-pl/-/ media/files/emea/poland/reports/2016/Colliers_International_Raport_Roczny_2016.pdf?smclient $=4 \mathrm{cfe}$ 4fad-00cc-481e-ac9f-87660f616600\&timeZoneId=CET

Devaney, S. (2010). Trends in office rents in the City of London: 1867-1959. Explorations in Economic History, 47(2), 198-212. https://doi.org/10.1016/j.eeh.2009.11.001

Englund, P., Gunnelin, Å., Hendershott, P. H., \& Söderberg, B. (2008). Adjustment in property space markets: taking long-term leases and transactions costs seriously. Real Estate Economics, 36(1), 81-109. https://doi.org/10.1111/j.1540-6229.2008.00208.x 
Eurostat. (2018). Harmonised index of consumer prices (HICP), HICP $(2015=100)$ - monthly data (monthly rate of change). https://ec.europa.eu/eurostat/web/hicp/data/database

Farrelly, K., Głuszak, M., \& Matysiak, G. (2014). Panel modelling of European office market rent dynamics and asymmetries. In European Real Estate Society Conference. Bucharest, Romania.

Hendershott, P. H., Lizieri, C. M., \& MacGregor, B. D. (2010). Asymmetric adjustment in the City of London office market. Journal of Real Estate Finance and Economics, 41(1), 80-101. https://doi.org/10.1007/s11146-009-9199-6

Hendershott, P. H., MacGregor, B. D., \& Tse, R. (2002a). Estimation of the rental adjustment process. Real Estate Economics, 30(2), 165-183. https://doi.org/10.1111/1540-6229.00036

Hendershott, P. H., MacGregor B. D., \& White, M. (2002b). Explaining real commercial rents using an error correction model with panel data. Journal of Real Estate Finance and Economics, 24(1-2), 59-87. https://doi.org/10.1023/A:1013930304732

Ho, K. H. D., Rengarajan, S., \& Glascock, J. (2014). An examination of the structure and dynamics of Singapore's maturing central area office market. Journal of Property Investment \& Finance, 32(5), 485-504. https://doi.org/10.1108/JPIF-02-2014-0013

Ibanez, M., \& Pennington-Cross, A. (2013). Commercial property rent dynamics in U.S. metropolitan areas: an examination of office, industrial, flex and retail space. Journal of Real Estate Finance and Economics, 46(2), 232-259.

https://doi.org/10.1007/s11146-011-9347-7

Ke, Q., \& White, M. (2013). A tale of two Chinese cities: the dynamics of Beijing and Shanghai office markets. Journal of Real Estate Portfolio Management, 19(1), 31-47.

https://doi.org/10.1080/10835547.2013.12089940
Kiehelä, S., \& Falkenbach, H. (2014). Modelling and forecasting central Helsinki office rents. International Journal of Strategic Property Management, 18(3), 292-306.

https://doi.org/10.3846/1648715X.2014.942720

McCartney, J. (2012). Short and long-run rent adjustment in the Dublin office market. Journal of Property Research, 29(3), 201-226. https://doi.org/10.1080/09599916.2012.689990

Mouzakis, F., \& Richards, D. (2007). Panel data modelling of prime office rents: a study of 12 major European markets. Journal of Property Research, 24(1), 31-53. https://doi.org/10.1080/09599910701297713

PAIiIZ and JP Weber Dudarski Sp. k. (2015). Investor's guide Poland. How to do business 2015. http://www.paiz.gov.pl/publikacje/jak_prowadzic_dzialalnosc_gospodarcza_w_polsce

Raslanas, S., \& Lukošienè, I. (2013). The determination of rents in shopping centers during recession period in Lithuania. International Journal of Strategic Property Management, 17(3), 221-232. https://doi.org/10.3846/1648715X.2013.819389

Simon, Z., Achsani, N., Manurung, A. H., \& Sembel, R. (2015). The determinants of rental rates and selling prices of office spaces in Jakarta: a macroeconometric model using VECM approach. International Journal of Economics and Finance, 7(3), 165-178. https://doi.org/10.5539/ijef.v7n3p165

Stevenson, S. (2007). Exploring the intra-metropolitan dynamics of the London office market. Journal of Real Estate Portfolio Management, 13(2), 93-98.

https://doi.org/10.1080/10835547.2007.12089774

\section{Appendix}

Table A1. The results of the ADF test for stationarity of variables used in the symmetric model (source: own study)

\begin{tabular}{|l|c|c|c|c|c|}
\hline \multicolumn{1}{|c|}{ Variable } & Test statistic & Critical value 1\% & Critical value 5\% & Critical value 10\% & Number of lags \\
\hline LNRent & -1.571 & -3.621 & -2.947 & -2.607 & 0 \\
\hline LNEmployment & -1.943 & -3.621 & -2.947 & -2.607 & 0 \\
\hline LNSupply & -0.904 & -3.621 & -2.947 & -2.607 & 0 \\
\hline LNRentC & $-3.453^{* *}$ & -3.628 & -2.950 & -2.608 & 0 \\
\hline LNEmploymentC & $-4.575^{\star}$ & -3.628 & -2.950 & -2.608 & 0 \\
\hline LNSupplyC & $-7.379^{*}$ & -3.628 & -2.950 & -2.608 & 0 \\
\hline
\end{tabular}

Note: time series stationary at ${ }^{*} \mathrm{p}<0.01 ;{ }^{* *} \mathrm{p}<0.05 ;{ }^{* * *} \mathrm{p}<0.1$.

Table A2. Johansen test results for variables from the long-term equation of the symmetric model (source: own study)

\begin{tabular}{|c|c|c|c|c|c|c|}
\hline $\begin{array}{c}\text { Number of cointegrating } \\
\text { vectors }\end{array}$ & Trace statistics & $\begin{array}{c}\text { Critical value } \\
5 \%\end{array}$ & $\begin{array}{c}\text { Critical value } \\
1 \%\end{array}$ & $\begin{array}{c}\text { Maximum } \\
\text { eigenvalue } \\
\text { statistic }\end{array}$ & $\begin{array}{c}\text { Critical value } \\
5 \%\end{array}$ & $\begin{array}{c}\text { Critical value } \\
1 \%\end{array}$ \\
\hline 0 & 56.7076 & 24.31 & 29.75 & 52.0300 & 17.89 & 22.99 \\
\hline 1 & $4.6776^{*, * *}$ & 12.53 & 16.31 & $4.5044^{*, * *}$ & 11.44 & 15.69 \\
\hline 2 & 0.1731 & 3.84 & 6.51 & 0.1731 & 3.84 & 6.51 \\
\hline
\end{tabular}

Note: one cointegrating vector at ${ }^{*} \mathrm{p}<0.01 ;{ }^{* *} \mathrm{p}<0.05 ;{ }^{* *} \mathrm{p}<0.1$. Johansen test for one lag. 
Table A3. The results of the Breusch-Godfrey test and the Breusch-Pagan test for the short-term equation in the symmetric model (source: own study)

\begin{tabular}{|c|c|c|c|c|}
\hline \multirow{2}{*}{$\begin{array}{c}\text { Number of } \\
\text { lags }\end{array}$} & \multicolumn{2}{|c|}{ Breusch-Godfrey test (1) } & chi2 & Prousch-Godfrey test (2) \\
\cline { 2 - 5 } & chi2 & Prob > chi2 & 1.697 & $0.1926^{* * *}$ \\
\hline 1 & 16.224 & 0.0001 & 2.002 & $0.3676^{* * *}$ \\
\hline 2 & 17.606 & 0.0002 & 3.568 & $0.3121^{* * *}$ \\
\hline 3 & 18.195 & 0.0004 & 7.510 & $0.1113^{* * *}$ \\
\hline 4 & 19.123 & 0.0007 & 5.89 \\
\hline \multicolumn{2}{|c|}{ chi2(4) } & $0.2078^{*}$ \\
\hline
\end{tabular}

Note: (1) the results of the Breusch-Godfrey test for the first version of the equation; (2) the results of the Breusch-Godfrey and Breusch-Pagan test for the equation with an additional explanatory variable; ${ }^{* *}$ lack of autocorrelation for $\mathrm{p} 0.1$ and 0.05 and 0.01 ; ${ }^{*}$ homoscedasticity of the equation with an additional explanatory variable for $\mathrm{p} 0.1$ and 0.5 and 0.01 . 